\title{
Developing Local Entrepreneurship Ecosystems by Foreign Investment
}

\author{
Alise Mačtama \\ PhD student, alise.mactama@inbox.lv \\ RISEBA University College of Business, Arts and Technology; Meza street 3, Riga, LV 1048, Latvia
}

\section{Arnis Sauka}

Professor of Entrepreneurship and Business Management, Head of the Centre for Sustainable Business, arnis.sauka@sseriga.edu

Stockholm School of Economics in Riga; Strelnieku street 4a, Riga, LV 1002, Latvia

\begin{abstract}
$\mathrm{T}$ he importance of foreign direct investment in transition economies has significantly increased over the last several decades. Foreign investors are recognized as important drivers shaping the local entrepreneurial ecosystem. This paper aims to explore investors' satisfaction with the factors previously identified as important for improving entrepreneurial ecosystems, that is, factors that both positively contribute to the development of local businesses as well as generate further foreign investment flow. Empirically we draw upon small case studies with managers of 38-42 key foreign investor companies in Latvia conducted in 2015, 2016, 2017, and 2018. In the first data collection wave, we identify key challenges that foreign investors face in Latvia. In the following data collection waves, we measure the development in the identified areas of concern and thus the overall entrepreneurial ecosystem of Latvia. Given that Latvia is a transition country in the advanced stage of development, the focus is on issues related to productivity and value added, including the availability

of high quality labor force, the efficiency of public sector, and favorable tax regimes as well as challenges posed by unethical and illegal behavior, labor shortages, and elements of uncertainty. Our results suggest that foreign investors see a number of challenges within the all afore-mentioned areas that are important parts of the entrepreneurial ecosystem. Moreover, our findings suggest that progress with regards to the improvement of certain areas such as those mentioned previously from the viewpoint of foreign investors, was relatively slow during the period of 20152018. Our key contribution is providing with an in- depth analysis of factors shaping the entrepreneurial ecosystem in an advanced transition economy-from the viewpoint of foreign direct investors. We explore investors' opinions with regard to the investment climate to summarize investors' suggestions on how the entrepreneurial ecosystem in Latvia could be further developed. Our findings provide a scope for tailor-made, targeted policy recommendations to achieve these goals.
\end{abstract}

Keywords: foreign direct investment;

entrepreneurship ecosystem; investment climate; transition economies
Citation: Mačtama A., Sauka A. (2019) Developing Local Entrepreneurship Ecosystems by Foreign Investment. Foresight and STI Governance, vol. 13, no 4, pp. 35-46. DOI: 10.17323/2500-2597.2019.4.35.46 
$\mathrm{T}$ he entrepreneurial ecosystem is a very complex system where various resources complement one another. For example, entrepreneurial education may support capital formation and capital formation may support government reform [Isenberg, 2010]. In transition economies, entrepreneurial ecosystems may also differ because certain resources were not available in various countries during the Soviet period. In this context, foreign direct investment plays a significant role in helping to fill the gaps and building an environment where such an entrepreneurial ecosystem can develop sustainably.

Each entrepreneurial ecosystem emerges under a unique set of conditions and circumstances. Often the same factors are equally important for the development of a sustainable foreign direct investment climate. Namely, the entrepreneurial ecosystem and foreign direct investment development may stimulate each other, because many entrepreneurial ecosystems are heavily mediated by foreign direct investment, which strongly resembles a truncated model [Mason, Brown, 2014].

The creation of regimes that encourage a sustainable and healthy investment environment has been set as a key priority for numerous countries around the globe [Coe, Helpman, 1994]. This includes countries that were formerly under Soviet control and only relatively recently regained their independence, some of them moving toward well-functioning market economies (see [Sauka, Chepurenko, 2017] for further discussion). It has been recognized that in such environments foreign direct investment plays a particularly significant role in reinforcing insufficient domestic funds to finance both ownership alteration and capital composition. Furthermore, foreign direct investment, as sound long-term capital inflow, may significantly contribute to introducing technology, managerial know-how and skills required for restructuring companies in transition economies [Popescu, 2014]. Needless to say, all these aspects are critical for the development of local entrepreneurial ecosystems.

Transition environments, depending on the stages of development, are often associated with uncertainty [Smallbone, Welter, 2006], constantly changing formal institutions, and not properly adapted informal norms [North, 1990]. This makes attracting and retaining foreign investors more challenging. Recognizing entrepreneurship as a context-specific phenomenon [Davidsson, 2004; Smallbone, Welter, 2001], this exploratory paper aims to contribute to the ongoing debate by exploring the key factors influencing the entrepreneurial ecosystem and investment climate in
Latvia, a country that was formerly a part of the Soviet Union and joined the European Union in 2004.

Similar to many other countries, foreign investors play a significant role in Latvia with regard to the development of the local entrepreneurial ecosystem and thus economic development. According to official statistics [CSB, 2017], one fifth of all companies in Latvia can be classified as foreign-owned. ${ }^{1}$ The revenue of these companies is approximately one half of the total turnover of all companies in Latvia. They employ $27 \%$ of the total workforce and contribute $48 \%$ of all tax payments. According to Bank of Latvia, the inflow of foreign investment in Latvia has been increasing relatively slowly since $2013^{2}$. One of the reasons for this could be the dissatisfaction of existing and potential foreign investors with factors shaping a favorable investment climate and entrepreneurial ecosystem, including human capital (education and labor), support services (infrastructure, etc.), and culture (social norms, etc.), as identified by [Isenberg, 2011]. In this study we aim to explore investors' satisfaction with those factors, with the assumption that improving foreign investors' satisfaction in certain problem areas will lead to both more investment and a better entrepreneurial ecosystem.

Empirically this paper draws on mini case studies: indepth expert interviews with major foreign investors in Latvia, conducted in 2015, 2016, 2017, and 2018. We aim to explore investors opinions with regard to the Latvian investment climate ${ }^{3}$. We also address investors' viewpoints on the strengths of the investment climate in Latvia and summarize investors' suggestions on how the investment climate could be improved.

More specifically, during the first data collection wave we identified the key challenges foreign investors face in Latvia, that is, the potential shortcomings within the entrepreneurial ecosystem of Latvia from an investment standpoint. In the following three data collection waves, we then assessed whether there are any positive developments in areas of concern and the overall entrepreneurial ecosystem of Latvia. Latvia is a transition country in an advanced stage of development [Sauka, Chepurenko, 2017] with a relatively mature market economy, which is arguably a result of entering the EU and NATO (2004) as well as joining OECD (2016). Therefore our proposal is that investors will mostly be concerned with issues related to productivity and value added, including the availability of a high quality workforce, the efficiency of the public sector (such as using e-tools in the communication, etc.), and favorable tax regimes. Yet we also

\footnotetext{
Foreign investors here are defined as companies with at least 145,000 EUR revenue and at least a 50\% share of foreign ownership.

See: http://www.liaa.gov.lv/en/invest-latvia/investor-business-guide/foreign-direct-investment, accessed 29.05.2019.

3 As 'investment climate' is a more appropriate term for use in non-academic conversation, we are using this term as a substitute for a more complex term, 'entrepreneurial ecosystem'.
} 
expect issues such as unethical and illegal behavior [Putnins, Sauka, 2015], labor shortages, and elements of uncertainty, especially with regards to the tax system [EBRD, 2016; 2017]. Finally, given that Latvia is a small and open economy, we propose that over the period of four years when data was collected, we will see the significant development of the entrepreneurial ecosystem of Latvia from the viewpoint of foreign investors.

The paper proceeds as follows. The next section reviews existing studies that address the state and development of the investment climate in various contexts. We first explore literature that addresses the impact of foreign investment on economic growth and local entrepreneurial ecosystems, then summarize key studies on the incentives for attracting foreign investors. We then proceed by exploring the impact of the economic environment on foreign direct investment and conclude with a brief description of the development of the investment climate in Latvia. In the third section we introduce the methodology, which is followed by the results section. The paper concludes with suggestions and policy implications. By doing so, we aim to provide up-to-date empirical evidence on the state of the investment climate in Latvia, thus providing scope for context-specific policy suggestions on the improvement of the investment climate and the development of the local entrepreneurial ecosystem in Latvia and other transition countries.

\section{Conceptual Framework}

\section{Foreign Investment, the Local Entrepreneurial Ecosystem and Economic Growth}

Daniel Isenberg categorizes factors contributing to a favorable entrepreneurial ecosystem into six domains: (i) politics (government, R\&D, leadership), (ii) finance (capital), (ii) culture (social norms, success stories), (iv) support services (non-governmental institutions, support professions, infrastructure, geo-location), (v) human capital (education, labor) and (vi) markets (entrepreneurs, network) [Isenberg, 2011]. These factors are connected in formal or informal way [Mason, Brown, 2014].

A large number of studies [Blomstrom, Kokko, 2003; Gorg, Hijzen, 2004; Liu, 2008; Barbosa, Eiriz, 2009] have aimed to explore the impact of foreign direct investment upon the development of local entrepreneurial ecosystems and economic growth. The findings reported by various studies are, however, somewhat mixed. Namely, some studies argue that countries with a relatively high dependence upon foreign capital exhibit slower economic growth than less dependent countries. Foreign investment has an initial positive effect on growth but in the long run the dependence on foreign investment exerts a negative effect on economic development [Dixon, Boswell, 1996]. In other words, it can lead to a situation where foreigners want to control the economy and influ- ence national security [Rivera-Batiz, Oliva, 2003]. Negative externalities such as unemployment, overurbanization, and income inequality perpetuate the problem [Almfraji, Almsafir, 2014].

Some studies, however, have not found evidence of any significant impact of foreign direct investment upon economic growth and thus consider the effect either neutral or weak [de Mello, 1999; Manuchehr, Ericsson, 2001; Carkovic, Levine, 2002]. Yet some recent studies find that foreign investment has a major positive impact on the development of the local entrepreneurial ecosystem. Creating new, often better jobs, bringing in know-how and generating innovations, and offering better products at lower prices, especially if the market allows investors to produce at lower prices or in greater volumes [Lipsey, Sjoholm, 2004] - these are the key benefits of foreign investors. Other arguments for inviting foreign investors to a particular country include providing access to human resources and the possibility of increasing efficiency and effectiveness [Devajit, 2012], thus strengthening the core components of the entrepreneurial ecosystem.

\section{Characteristics of the Entrepreneurial Ecosystem that Attract Foreign Investors}

A recent model by Cerrato et al. [Cerrato et al., 2016] identifies the main dimensions or indicators of firms' internationalization: internationalization from the demand side, resources located abroad, geographical scope, international orientation, internationalization of the business network, and financial internationalization.

The legal framework is often highlighted as one of the most important factors determining such choices. But, as the experience of some transitional economies shows, overemphasizing the formal legislation without paying attention to other important aspects of the entrepreneurial ecosystem may lead to poor investment decisions. Moreover, such factors as the cost of resources and the cost of labor in particular might be no less important especially for foreign direct investors seeking to locate manufacturing operations in a global supply chain for a worldwide market [Bevan et al., 2004].

Previous studies also show that physical, cultural and institutional factors matter [Choi et al., 2016]. In particular, such formal institutions as a stable banking sector, foreign exchange and trade liberalization, and the rule of law are all critical elements of the entrepreneurial ecosystem [Bevan et al., 2004].

The knowledge demonstrated by a potential investor about the 'market of interest' has also been emphasized as another factor that can foster investment flow [Eriksson et al., 1997]. One way to attract both internationally oriented companies and firms that may also decide to invest in particular countries is by supplying them with the necessary information about the host country [Fletcher, Harris, 2012]. 
A very important distinction, recently introduced by some scholars, is made between two types of assets - created and natural - which are both important factors for creating a better ecosystem to attract foreign investment. 'Created assets' are factors directly related to the institutional environment, while 'natural assets' include, for instance, the availability of raw material or cheap labor. Several studies show that in most cases 'created assets' are more important for investors than 'natural assets' when it comes to making an investment decision [Narula, Dunning, 2000; Bevan et al., 2004]. Namely, existing evidence suggests that foreign investments flow into countries with better institutional infrastructure [Choi et al., 2016]. Thus, speculation about the crucial role of path dependence in establishing entrepreneurial ecosystems is counterproductive, since in developing economies there is still work being done on improving education, research, legal, and regulation systems. Countries, especially transitional ones, may compensate for a deficit of natural assets by improving the conditions for foreign investors.

\section{Foreign Investment and Entrepreneurial Ecosystems: Developed vs. Developing Countries}

Transition economies are an interesting and relevant setting to explore the impact of institutions as the entire set of formal and informal institutions was built anew in the early 1990s [Smallbone, Welter, 2001]. Even now, in many CIS and CEE countries, including Latvia, the quality of institutions reflects both the legacy of communism and a newly developed ecosystem with private ownership, capital markets, and legal and institutional infrastructure [Bevan et al., 2004].

Indeed, initially the radical economic and political reforms caused virtually all members to experience economic recession at different levels. In many cases, the growth of CEE (and also CIS) countries was driven particularly with the help of external funding [Sauka, Chepurenko, 2017]. Also, much of the knowhow was 'imported', often arriving in the form of foreign investment, thus considerably improving the local entrepreneurial landscape.

Yet in many countries, including Latvia, the flow of foreign investment became substantial and relatively stable only with the enlargement of the European Union (EU) in the early 2000s, that is, the adoption of many legal norms and higher transparency. These elements are both core aspects of the entrepreneurial ecosystem for investors in the West and lower the transaction costs for 'western' companies entering the CEE or CIS markets [Bevan et al., 2004].

The inflow of foreign investment can facilitate technology transfers from developed to developing countries, which is particularly important within a transition setting. Domestic firms located in transition countries tend to benefit more from the presence of multinational firms because of factors such as the higher absorptive capacity, better technology, and superior marketing skills [Anwar, Nguyen, 2011].

A large number of studies explore foreign direct investment's impact upon economic growth, but only some focus on the synergy between foreign direct investment companies and local firms in transitional environments. Recent studies [Giroud, Scott-Kennel, 2009; Anwar, Nguyen, 2011] show that these two factors together are the real economic drivers that help countries improve the quality of the entrepreneurial ecosystem and thus to increase their competitiveness in the global arena. Local firms have access to local resources, information, and valuable people with innovative ideas, while foreign corporations can provide enormous capital and R\&D opportunities to develop businesses across borders. This synergy appears not only within one country, but nowadays can easily be seen between highly developed countries and emerging markets.

Economic liberalization has led many local firms in emerging economies to actively acquire foreign technological and managerial knowledge in order to strengthen their competitive positions [Chen et al., 2016; Chittoor et al., 2009; Elango, Pattnaik, 2007; Xu, Meyer, 2013]. Factors that enhance competitiveness are connected with more highly skilled employees, more capital intensity, differences in the scale of production and factor combination choices, knowledge, technology development, and other aspects. Overall this fosters the entrepreneurial ecosystem of the respective country and helps foreign direct investment companies develop their businesses and better use locally available resources. For instance, a number of studies on Indonesia show that foreign plants have higher productivity than locally owned plants [Takki, Ramstetter, 2003] and that plants that change ownership from local to foreign increase their level of productivity. This means that local firms also 'take advantage' of FDI while increasing their competitiveness and improving their productivity [Bevan et al., 2004].

\section{Methodology}

This paper draws on mini case studies - in-depth expert interviews with the CEOs of key foreign investors in Latvia and members of the Foreign Investors' Council of Latvia. The interviews were conducted in four waves: in 2015, 2016, 2017, and 2018. Namely, from September to early November 2018, we interviewed the same 38 (out of 42) companies that took part in the 2017 study. In addition, two new companies joined the sample in 2018. Twenty-eight CEOs took part in the survey in 2015, while 32 took part in 2016. Altogether, the companies (including their 
subsidiaries) that were interviewed in 2018 represent more than $30 \%$ of the total foreign direct investment in Latvia and contribute to $9 \%$ of Latvia's total tax revenue and $18 \%$ of total profit while they employ $4 \%$ of the total workforce of companies with turnover above EUR 145,000 and 50\% foreign capital [CSB, 2017].

In the first wave, in 2015, we started out by asking foreign investors to identify three to five key areas of concern with respect to the sustainable economic development of the investment climate in Latvia (open question). Respondents were also asked to specify any immediate of short-term priorities for development as well as long-term one. Discussion then proceeded with the following question: "Why have you invested in Latvia and, apart from solving the concerns mentioned previously, what would other potential drivers be for you to increase investment in this country?" Whenever possible, the respondents were asked to provide examples illustrating their opinions.

The interviews then continued with investors' evaluations of the key drivers of Latvia's economic competitiveness. We provided investors with a list of the most important factors affecting companies as derived from discussions within the Foreign Investment Council of Latvia Sustainable Economic Development Working Group. Respondents were asked to evaluate these factors on a scale from 1 to 5 , where 1 means that Latvia is not competitive with regard to this factor and 5 means that Latvia is very competitive in this area.

Drawing on the results of the 2015 survey, the next three waves aimed to address the following three issues: (i) Do investors see progress with regard to policy initiatives to meet the main challenges identified in 2015?; (ii) What has been done and what still remains to be done (according to the viewpoint of foreign investors in Latvia) to improve the investment climate in Latvia?; (iii) Are there any new (emerging) challenges that policymakers should be made aware of?

Additionally, in all three waves (2016, 2017, and 2018) we asked investors for their perspective on whether the investment attractiveness of Latvia has improved over the past 12 months. We also asked whether investors see progress with regard to policy initiatives to meet the main challenges identified in the 2015 study and how investors evaluate the government's efforts and current policy initiatives aimed at improving the investment climate in Latvia. As in the 2015 survey, we also asked foreign investors whether, and under what conditions, they plan to increase their investment in Latvia. Finally, in the 2018 survey, we asked foreign investors to identify the best and worst decisions or policy initiatives that have been introduced by the Latvian government over the last five years and whether they had a positive or negative impact upon the business environment of Latvia.

\section{The Viewpoints of Foreign Investors on the Investment Climate in Latvia: Results from $2015,2016,2017$, and 2018}

\section{The Evaluation of the Investment Climate in Latvia by Foreign Investors}

This section presents an assessment of the economic competitiveness of Latvia, more specifically, an evaluation of the investment climate in Latvia by foreign investors operating in the country. The main factors that could potentially influence Latvian competitiveness were derived by reviewing the relevant academic literature or emerged from in-depth discussions with the Foreign Investors' Council in Latvia (FICIL) Sustainable Economic Development Working Group in 2015. Foreign investors' assessments of the drivers of Latvia's competitiveness consist of the following indicators: the availability of labor, the efficiency of labor, the demand for products and services, the attitude towards foreign investors, the quality of business legislation, the quality of education and science, the quality of health and social security, hard infrastructure, investment incentives, soft infrastructure, and demography. Additionally, foreign investors were asked to evaluate the standard of living in Latvia. All the aforementioned factors are also important components of the entrepreneurial ecosystem.

During the 2015 study, 28 randomly selected foreign investors in Latvia evaluated each of these indicators or potential drivers of Latvia's economic competitiveness. The same 28 respondents as well as four new companies participated in the evaluation of the same indicators in 2016, while in 2017 an additional 10 companies joined the sample. In 2018, we interviewed the same 38 (out of 42) companies that took part in the 2017 study. In addition, two new companies joined the sample in 2018.

We provided respondents with an evaluation scale from 1-5, where 1 means that the indicator is not competitive and 5 means that the indicator is very competitive. Some indicators included one item, while some included several items. We calculated a simple average for each indicator. Twenty-six of the 28 investors interviewed provided an evaluation for most of the indicators in 2015: all 32, 42, and 40 respondents took an active part in evaluating the indicators in the 2016, 2017, and 2018 studies, respectively. The results are presented in Table 1 .

As illustrated by Table 1 , for all four years $(2015,2016$, 2017 and 2018) foreign investors in Latvia mostly evaluated the potential drivers of the economy as above average. Similarly to previous years, in 2018 investors were also relatively satisfied with the 'soft infrastructure', measured as 'business culture in Latvia' (3.5 out of 5 in 2018 compared to 3.4 in 20152017) and 'demand for products and services' (3.4 out of 5 in 2018 and 2017). In 2018, however, the 'attitude 
towards foreign investors' was evaluated as highly as 3.6 out of 5 (compared to 3.1 in 2017 and 3.2 in 2015 and 2016), which was the best assessment by foreign investors as explored in all four data collection waves. Investors were, however, least satisfied with 'demography'. The evaluation of this factor gradually decreased from 2015-2017 (i.e., 2.0 out of 5 in 2015, 1.8 in 2016 and 1.6 in 2017), yet increased slightly in 2018 (1.7 out of 5).

The investors' assessment of the quality of the 'health and social system' improved in 2018 compared to 2015-2017 (2.6 in 2015, 2.5 in 2016 and 2017, 2.9 in 2018). However, a decrease can be observed in 'efficiency of labor' (3.1 in 2017 to 2.9 in 2018), whereas the 'availability of labor' remained at the level of 2017 (2.7 out of 5). It is important to note that there was a decrease in the component 'availability of blue-collar labor' (from 2.5 in 2017 to 2.3 in 2018). 'Quality of business legislation' and 'investment incentives', however, were assessed at the same level by foreign investors in 2018 and 2017 (3.2 and 2.8, respectively).

The assessment of 'hard infrastructure' decreased from 3.4 in 2017 to 3.2 in 2018 and was driven by a decrease in the assessment of 'energy resources' (3.0 in 2018 compared to 3.4 in 2017) as well as 'low production costs' (2.9 in 2018 compared to 3.2 in 2017). Also, the assessment of the 'quality of education and science' decreased slightly (from 3.1 in 2017 to 3.0 in 2018) following an increase from a low of 2.6 in 2016 to 3.1 in 2017. Finally, the standard of living in Latvia was evaluated at 3.9 out of 5 in 2018 , which is a 0.2 increase compared with 2017 and at the same level as 2016. (See Table 1)

By increasing the satisfaction of foreign investors with regards to aforementioned factors, a country such as Latvia potentially stimulates and maintains the involvement of foreign investors in the entrepreneurial ecosystem. This is important since investors tend to reinvest their experience and wealth as mentors, capital investors, and serial entrepreneurs [Mason, Brown, 2014].

\section{The Attractiveness of the Investment Climate in Latvia}

One of the key aims of this study is to measure the progress of the development of the investment climate in Latvia. To do so, similarly to 2016 and 2017, investors in the 2018 survey were also asked for their perspective on whether the investment attractiveness of Latvia had improved over the past 12 months. Investors could evaluate the investment attractiveness of Latvia using a 5-point scale, where 1 means that investment attractiveness had not improved at all, 2 means that there have only been minor improvements, 3 means that there have been some positive improvements, 4 means yes, investment attractiveness has improved and 5 means yes, investment attractiveness has improved significantly.
All 40 respondents answered this question, in most cases evaluating the development of investment attractiveness with either 2 (there have only been minor improvements) or 3 (some positive improvements). No respondents, however, answered with a 5 , that is, that investment attractiveness had improved significantly. On average, the development of the investment climate in Latvia over the past year was evaluated with 2.5, which is at the same level as the evaluation a year earlier and 0.5 higher in comparison to answers to the same question in 2016 (see Table 2).

In this context it is important to highlight that the attractiveness of a specific entrepreneurial ecosystem stimulates the interest of large and international companies, which is very crucial for its development. Even a small improvement in investment attractiveness may lead to the interest of new companies and foreign investors in Latvia. This in turn could potentially generate some benefits, including the increase of recruitment levels, the provision of training for employees, and sources for various spin-offs providing commercial opportunities for local business and thus further contributing to the development of the national entrepreneurial ecosystem [Mason, Brown, 2014].

\section{Key Challenges Faced by Foreign Investors in Lat- via: Progress or Regression?}

During the 2015 and 2016 surveys, a number of key challenges were identified that foreign investors in Latvia faced while developing their businesses. These included demography, access to labor, level of education and science, quality of business legislation, quality of the tax system, support from the government and communication with policymakers, unethical or illegal behavior by entrepreneurs, unfair competition, uncertainty, the court system, and the healthcare system in Latvia. In the 2018 survey, we asked the 40 largest foreign investors in Latvia whether, in their opinion, there had been any progress during the previous 12 months within these areas of concern. The findings from the 2018 study are summarized in Figure 1a, while, for comparison, the findings from the 2017 study are displayed in Figure $1 \mathrm{~b}$.

As exemplified by Figure 1b, foreign investors interviewed in the 2017 survey did not see any progress with regard to access to labor. On the contrary, access to labor seems to be an even greater challenge in 2018 than 2017. In 2018, however, the situation looks somewhat more positive with regard to demography and the healthcare system, with substantially more investors (compared to 2017) answering that progress in these areas has been made at least 'partly'.

A large number of the foreign investors interviewed were also not satisfied with the improvements in uncertainty (22 saw no improvements in 2018 as well as in 2017). The situation with regard to the court system and quality of business legislation is also still far from 
Table 1. Foreign Investor Satisfaction with Factors Impacting the Inflow of Foreign Investment and the Entrepreneurial Ecosystem, 2015-2018

\begin{tabular}{|c|c|c|c|c|}
\hline & 2015 & 2016 & 2017 & 2018 \\
\hline Number of observations (n) & 28 & 32 & 42 & 40 \\
\hline Soft infrastructure & 3.4 & 3.4 & 3.4 & 3.5 \\
\hline Business culture in Latvia & 3.4 & 3.4 & 3.4 & 3.5 \\
\hline Efficiency of labor & 3.2 & 3.2 & 3.1 & 2.9 \\
\hline Attitude towards foreign investors & 3.2 & 3.2 & 3.1 & 3.6 \\
\hline Investment incentives & 2.8 & 2.8 & 2.8 & 2.8 \\
\hline Quality of business legislation & 3.2 & 3.1 & 3.2 & 3.2 \\
\hline Monetary policy & 4.0 & 4.1 & 3.9 & 3.7 \\
\hline Tax system & 3.1 & 2.8 & 2.8 & 3.1 \\
\hline Legal system & 2.6 & 2.6 & 2.8 & 2.9 \\
\hline Hard infrastructure & 3.2 & 3.3 & 3.4 & 3.2 \\
\hline Defense & 3.4 & 3.6 & 3.6 & 3.6 \\
\hline Low production costs & 3.3 & 3.2 & 3.2 & 2.9 \\
\hline Infrastructure (roads, electricity, etc.) & 3.1 & 3.1 & 3.3 & 3.2 \\
\hline Energy resources & 2.8 & 3.3 & 3.4 & 3.0 \\
\hline Demand for products and services & 3.1 & 3.1 & 3.4 & 3.4 \\
\hline Domestic demand & 2.8 & 2.6 & 2.9 & 2.8 \\
\hline External demand (exports) & 3.3 & 3.3 & 3.7 & 3.8 \\
\hline Industry traditions & 3.4 & 3.5 & 3.5 & 3.6 \\
\hline Availability of labor & 3.0 & 3.1 & 2.7 & 2.7 \\
\hline Availability of labor at the management level & 3.4 & 3.5 & 2.9 & 3.0 \\
\hline Availability of blue-collar labor & 2.7 & 2.8 & 2.5 & 2.3 \\
\hline Quality of education and science & 2.8 & 2.6 & 3.1 & 3.0 \\
\hline Education, science, and innovation & 2.8 & 2.6 & 3.1 & 3.0 \\
\hline Quality of health and social security & 2.6 & 2.5 & 2.5 & 2.9 \\
\hline Health system & 2.5 & 2.4 & 2.4 & 2.7 \\
\hline Social security & 2.8 & 2.5 & 2.6 & 3.0 \\
\hline Demography (population growth) & 2.0 & 1.8 & 1.6 & 1.7 \\
\hline Standard of living in Latvia & 3.4 & 3.9 & 3.7 & 3.9 \\
\hline
\end{tabular}

satisfactory in the viewpoint of foreign investors, yet progress in 2018 was evaluated as somewhat better than in 2017.

Also, the evaluation of progress with regard to the tax system improved slightly in 2018 compared to the 2017 study, with more respondents in 2018 indicating that progress has been achieved at least 'partly'. Slightly more foreign investors also see progress with regard to unethical or illegal behavior by entrepreneurs and unfair competition in 2018 compared to 2017, even though approximately half of the respondents still report that no progress had been achieved in this area in 2018 (see Figure 1).

Finally, approximately the same number of respondents in 2017 and in 2018 answered that they had seen progress in the support from the government and communication with policymakers, or answered that progress has been achieved 'partly', or mentioned that there has been no progress in this area over the past 12 months.

\section{Three Key Challenges Identified: Problems and Solutions}

Of all the issues that were raised by the 2015-2017 studies, arguably three stand out. These are (i) the availability and quality of the workforce in Latvia, (ii) corruption in the public sector and the shadow economy, and (iii) the effectiveness of the public sector with regard to improving the business environment in Latvia. In the 2018 study, we thus aimed to address all three issues in somewhat greater depth, asking the 40 largest foreign investors in Latvia that participated in the study to comment and, even more importantly, provide potential solutions that might help achieve better progress with regard to solving these areas of concern. The key findings are summarized below. 


\section{Figure. 1. Foreign Investors' Assessment of the Progress over the Past 12 Months for Key Areas of Concern Identified in 2015 and 2016}

a) Findings from $2018(n=40)$

The healthcare system in Latvia

The court system in Latvia

Uncertainty

Unethical or illegal behaviour by entrepreneurs, unfair competition Support from the government and communication with the policy makers

Quality of the tax system

Quality of the business legislation

Level of education and science

Access to labor

Demography
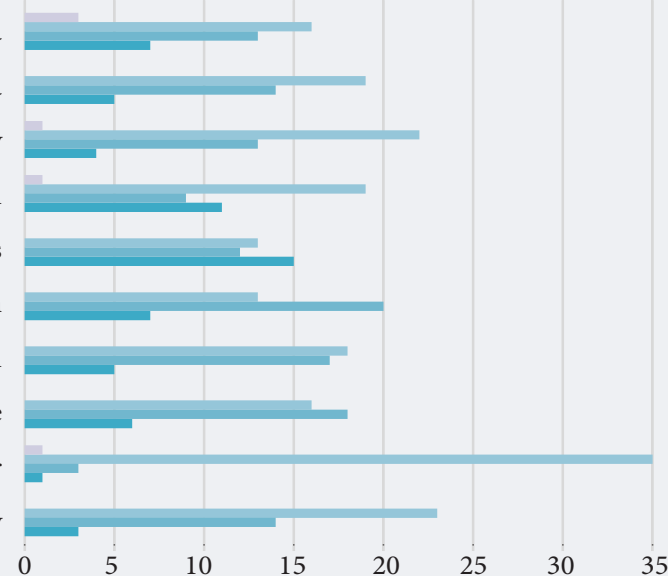

b) Findings from $2017(n=42)$

The healthcare system in Latvia

The court system in Latvia

Uncertainty

Unethical or illegal behaviour by entrepreneurs, unfair competition Support from the government and communication with the policy makers

$$
\begin{array}{r}
\text { Quality of the tax system } \\
\text { Quality of the business legislation } \\
\text { Level of education and science } \\
\text { Access to labor } \\
\text { Demography }
\end{array}
$$

partly yes

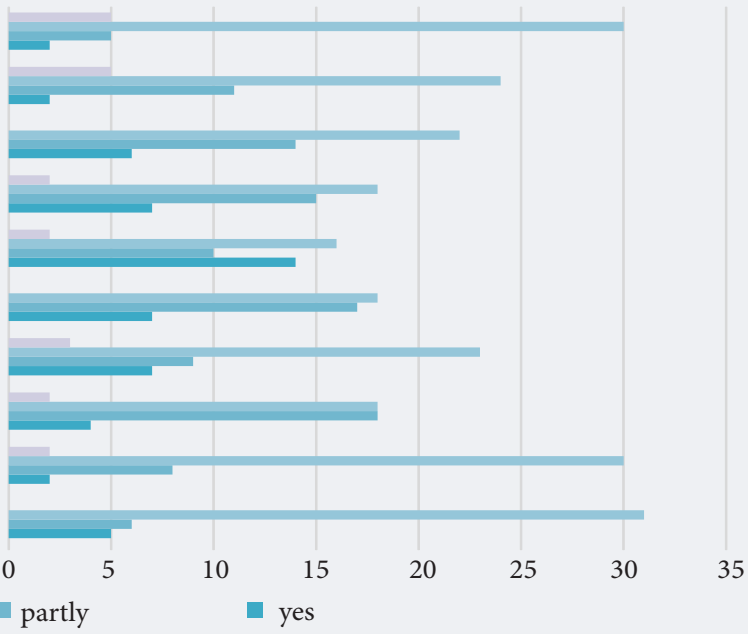

$\mathrm{n} / \mathrm{a}$

$\square$ no

- partly

yes

Note: Evaluation scale from 1-5, where 1 means that the indicator is not competitive and 5 means that the indicator is very competitive. Source: authors' own calculations.

\section{Availability and Quality of the Workforce, including the Quality of Education and Science for Achieving Productivity Growth}

On a positive note, a number of foreign investors in Latvia that we interviewed actually argued that the situation had improved with regard to the quality of labor as well as education and science. However, the following excerpts from interviews show that the availability and quality of the workforce is still a major problem in Latvia.

"Workforce availability is a problem in Latvia; you could say that nothing is being done to improve the situation.
Table 2. Progress of Investment Climate Development in Latvia over the Past 12 Months: 2016, 2017, and 2018 studies

\begin{tabular}{|c|c|c|}
\hline Year & Number of observations & Rank \\
\hline 2018 & 40 & 2.5 \\
\hline 2017 & 42 & 2.5 \\
\hline 2016 & 32 & 2.0 \\
\hline
\end{tabular}

Note: Scale of 1-5 where 1 means investment attractiveness has not improved at all and 5 means investment attractiveness has improved significantly.

Source: authors' own calculations. 
To be honest, it seems like the government doesn't even acknowledge that there is a major problem." (Consultancy and IT company)

"We are preparing ourselves for a situation where the availability of labor will become even worse, when low-skilled labor will be even more scarce and more expensive at the same time." (Retail trade and service company)

"No major change in the last few years. Regarding quality - it feels okay. The biggest problem is productivity." (Wholesale and retail company)

"We cannot really complain about the unavailability of a low-quality workforce; however, the quality of education in Latvia is an issue, it's a real challenge to keep up with, and there are some pockets of interest in this area but no visible improvements yet." (Consultancy and IT company)

A number of suggestions were provided by foreign investors to solve this challenge with regard to labor. The suggestions on availability were as follows:

"With regard to labor availability and quality, potential improvements can be divided into two main directions:

\section{Choosing a career before starting a career}

It is necessary to encourage pupils to understand the various possibilities of further study and the types of work each day in different occupations, in order to reduce the number of students who make poorly considered choices.

\section{Quality and practical experience of higher education}

"One needs to think about ways to support regional mobility, housing, better transport systems locally. Also, one needs to promote regional development - strengthen the regional centers. I haven't heard any evaluation of the operation of tax-free zones - maybe there should be something else to incentivize business?" (Retail trade and service company)

"We need to open borders for both skilled and lowskilled labor. And there are opportunities. Otherwise, soon you will have to wash your own dishes in the restaurant after eating your lunch." (Finance and banking company)

As to suggestions on quality, one can name the following:

"In the education sector there is a tendency towards segmentation and inequality, which is dangerous and bad for such a small country. It is good that there was the decision about optimizing - the same should be done in higher education." (Finance and banking company)

"It is important to strengthen technical and engineering studies in Latvia, develop educational programs in cooperation with employers in Latvia and consider reasonable opportunities for the migration of workers." (Manufacturing company)
"Sick leave is a huge problem and there should be better control over who grants it and on what conditions, etc. Employees are abusing it and my suspicion is that not all doctors are honest in this area!" (Manufacturing company)

"Streamlined procedures for importing high-quality labor." (Consultancy and IT company)

In the context of developing a sustainable entrepreneurial ecosystem, higher education is indeed a very important factor. What is especially important is the development of $R \& D$ at higher education institutions, which can create disruptive technologies and innovative ideas, contributing to both the quantity and quality of entrepreneurship [Carvalho et al., 2010]. Furthermore, knowledge exchanges between industry and the academic system is very crucial [Etzkowitz, 2008]. The results of this study suggest that quality of education and science, involvement in R\&D, and collaboration with various stakeholders still have potential for further development.

\section{Corruption in the Public Sector and the Shadow Economy}

Overall, foreign investors argue that the situation is also improving with regard to corruption in the public sector and the shadow economy. However, investors also clearly emphasized that many things should still be done in this regard. The following solutions were provided during the 2018 interviews:

"Currently in our country there's a feeling that you don't get punished if you break the law." (Finance and banking company)

"A number of actions have been taken and we can see some results. Having said that, we lack transparency on the actions taken and activities implemented, with particular examples of actions and their consequences." (Retail trade and service company)

"The only thing left to do is to bring the cases to court and prosecute. If the courts are really corrupt, then it's very sad. It (corruption) won't go away by itself." (Consultancy and IT company)

"This takes a generation to change. The situation has improved compared to twenty years ago. The current generation and new politicians that we saw in the last election have a more honest agenda. The corruption prevention office is working better, the State Revenue Service is also doing better: they have improved control mechanisms. But corruption is still there." (Real estate company)

"Non-bank crediting and 'payday loans' are huge in Latvia and are politically safeguarded. This is not normal. Hundreds of thousands of those who should never have received loans have received them. Do we really want a 25-year-old to get addicted to this system?" (Finance and banking company) 


\section{The Effectiveness of the Public Sector with Regard to Improving the Business Environment in Latvia}

The effectiveness of the public sector with regard to improving the business environment in Latvia has often been emphasized by foreign investors in Latvia and is reflected in the findings of all four interview waves. In the 2018 study, investors also highlight a number of challenges:

"It seems that bureaucracy is the main issue that hinders the business environment in Latvia. Everyone can invest in Latvia, but they have to be ready to come up against heavy red tape." (Finance and banking company)

"The major thing that Latvia needs to improve is automation and digitalization. IT has the tools for Latvia to become more efficient. Estonia is a great example." (Consultancy and IT company)

"There are still a lot of things to improve in this regard. If you build something in Riga, construction permits take a lot of time and energy. Different Latvian government institutions have 30 days to answer a message, and then it becomes a kind of ping-pong game where they always take their time to answer company questions. Not at all effective when trying to get construction permits. Thirty days should be the maximum for them to answer; they take it as a minimum." (Retail trade and service company)

The following are suggestions for improving the effectiveness of the public sector in Latvia:

"Structural reforms in the whole public sector by reviewing the existing activities and designing the most efficient future public processes, which are client-oriented and as digital as possible." (Professional assurance and advisory services company)

"Cooperation among ministries is very poor and should be improved. It seems that the entire system of how the government operates and how legislation is written in Latvia is based on the principle "Catch the thief!" But I do not think I deserve to be perceived as a thief!" (Finance and banking company)

"The public sector remains largely inefficient, where, to our knowledge, the reasons are a lack of qualified labor resources that would be willing to work in the public sector and, on the other hand, the slow speed to market, i.e., the time required to adopt new technologies, approaches, or ideas." (Retail trade and service company)

"The main problem with digitalization is that we are trying to implement it in a corrupt environment, so there are not many supporters for it, which is slowing down the whole process. Certain public procurement projects are carried out with elections in mind, so this is not always done in the best interests of the country, but rather with the number of votes in mind. We need to increase transparency." (Manufacturing company)
As also exemplified by the results of this study, there are different components of the means and instruments governments can use to foster the entrepreneurial ecosystem. These include improving legislation and the regulatory environment, tax law, labor rights, bankruptcy laws, the business formation process, the educational system, awareness building, access to finance and financial support, technology exchange, and networking. Furthermore, it should be taken into account that the emphasis on improving the ecosystem might change from reducing the unemployment rate to how to achieve the needed qualifications for employees so that foreign companies can invest more and, thus, further make their contribution to improving the entrepreneurial ecosystem [Fuerlinger et al., 2015].

\section{Conclusions and Implications}

This paper aims to provide an assessment of the investment climate and entrepreneurial ecosystem in Latvia from the perspective of foreign investors, drawing on both the conceptual framework and empirical evidence from interviews with key foreign investors in Latvia, conducted in 2015, 2016, 2017, and 2018. The results of the 2018 study suggest that the investment attractiveness of Latvia, according to foreign investors, has remained the same compared to the situation one year earlier. Also, the investors' assessment with regard to policymakers' efforts to improve the investment climate in Latvia over the past year has also been evaluated at the same level as the 2017 study. The overall conclusion is that there is still substantial potential to increase both policymakers' efforts and the resulting overall foreign investment climate in Latvia.

Similarly to the 2016 and 2017 studies, foreign investors were once again asked to evaluate whether there has been any progress within key areas of concern identified back in 2015. The results of the 2018 study suggest that, compared to the findings of the 2017 study, the situation looks somewhat more positive with regard to demography and the healthcare system, that is substantially more investors highlighted that progress in these areas had been made at least 'partly', which was rarely the case in previous data collection waves. Access to labor, however, seems to be an even larger challenge in 2018 compared to 2017.

The foreign investors were also not satisfied with the improvements in uncertainty. The situation with regard to the court system and the quality of business legislation is also still far from satisfactory according to foreign investors, yet progress in 2018 was evaluated as slightly better than in 2017. Finally, slightly more foreign investors have also seen progress with regard to unethical or illegal behavior by entrepreneurs and unfair competition in 2018 compared to 2017. 
To summarize, of all the issues highlighted by the results of the 2015, 2016, and 2017 survey waves, arguably three stand out. These are (i) the availability and quality of the workforce in Latvia, (ii) corruption in the public sector and the shadow economy, and (iii) the effectiveness of the public sector with regard to improving the business environment in Latvia.

The factors that drive foreign investors to choose Latvia seem to be similar to factors that are crucial for a sustainable entrepreneurial ecosystem. Overall, however, of the six domains classified by [Isenberg, 2011], factors such as politics, human capital, and the market should be significantly improved to develop a sustainable ecosystem and at the same time increase foreign direct investment attractiveness in
Latvia. In this context, it is very important for policymakers to have one strategy for the whole country, instead of offering different conditions in each region and city.

We believe that our findings provide scope for further research. Deeper analysis could be made regarding the unused potential of countries from the CIS or CEE, including Latvia, to increase overall competitiveness, including by further developing the business climate. This means that local firms should be a stimulating factor for foreigners to enter, and that they should learn from each other. There is also a lack of research that compares local and foreign companies in the context of CEE and the CIS as regards their roles in shaping an entrepreneurial ecosystem.

\section{References}

Almfraji M.A., Almsafir M.K. (2014) Foreign direct investment and economic growth, literature review from 1994 to 2012. Social and Behavioral Sciences, vol. 129, pp. 206-213.

Anderson E., Gatignon H. (1986) Modes of entry: A transactions cost analysis and propositions. Journal of International Business Studies, vol. 17, no 3, pp. 1-26.

Anwar S., Nguyen L.P. (2011) Foreign direct investment and export spillovers: Evidence from Vietnam. International Business Review, vol. 20, pp. 177-193.

Barbosa N., Eiriz V. (2009) Linking corporate productivity to foreign direct investment: An empirical assessment. International Business Review, vol. 18, pp. 1-13.

Bevan A., Estrin S., Meyer K. (2004) Foreign investment location and institutional development in transition economies. International Business Review, vol. 12, pp. 43-64.

Blomstrom M., Kokko A. (2003) The economics of foreign direct investment incentives. Foreign Direct Investment in the Real and Financial Sector of Industrial Countries (ed. H. Herrmann), Heidelberg, Dordrecht, London, New York: Springer, pp. 37-60.

Carkovic M., Levine R., (2002) Does Foreign Direct Investment Accelerate Economic Growth? (University of Minnesota Working Paper), Minneapolis, MN: University of Minnesota.

Carvalho L., Costa T., Dominguinhos P. (2010) Creating an entrepreneurial ecosystem in higher education. New achievements in technology education and development (ed. S. Soomro), New York: InTech, pp. 1-20. Available at: https://www.intechopen. com/books/new-achievements-in-technology-education-and-development/creating-an-entrepreneurship-ecosystem-inhigher-education, accessed 23.03.2019.

Cerrato D., Crosato L., Depperu D. (2016) Archetypes of SME internationalization: A configurational approach. International Business Review, vol. 26, pp. 286-295.

Chen P., Danchi T., Jean R.B. (2016) Foreign knowledge acquisition through inter-firm collaboration and recruitment: Implications for domestic growth of emerging market firms. International Business Review, vol. 25, pp. $221-232$.

Chittoor R., Sarkar M.B., Ray S., Aulakh P.S. (2009) Third-world copycats to emerging multinationals: Institutional changes and organizational transformation in the Indian pharmaceutical industry. Organization Science, vol. 20, no 1, pp. $187-205$.

Choi J.J., Lee S.M., Shoham A. (2016) The effects of institutional distance on FDI inflow: General environmental institutions (GEI) versus minority investor protection institutions (MIP). International Business Review, vol. 25, pp. $114-123$.

Coe D.T., Helpman E. (1994) International R\&D spillovers. European Economic Review, vol. 39, pp. 859-887.

CSB (2017) Statistical Yearbook of Latvia 2017, Riga: Central Statistical Bureau of Latvia.

Davidsson P. (2004) Researching Entrepreneurship, Heidelberg, Dordrecht, London, New York: Springer.

De Mello L.R. (1999) Foreign direct investment-led growth: Evidence from time series and panel data. Oxford Economic Papers, vol. 51, no 1, pp. 133-151.

Devajit M. (2012) Impact of Foreign Direct Investment on Indian economy. Research Journal of Management Sciences, vol. 1, no 2, pp. 29-31.

Dixon W.J., Boswell T. (1996) Dependency, disarticulation, and denominator effects: Another look at foreign capital penetration. American Journal of Sociology, vol. 102, no 2, pp. 543-562.

EBRD (2016) EBRD transition report 2015-16. Rebalancing finance, London: European Bank of Reconstruction and Development. 
EBRD (2017) EBRD transition report 2016-17. Transition for all: Equal opportunities in an unequal world, London: European Bank of Reconstruction and Development.

Elango B., Pattnaik C. (2007) Building capabilities for international operations through networks: A study of Indian firms. Journal of International Business Studies, vol. 38, no 4, pp. 541-555.

Eriksson K., Johanson J., Majkgard A., Deo Sharma D. (1997) Effect of Variation on Knowledge Accumulation in the Internationalization Process. International Studies of Management and Organization, vol. 30, no 1, pp. $26-44$.

Etzkowitz H. (2008) The Triple Helix: University-Industry-Government Innovation in Action, London: Routledge.

Fletcher M., Harris S. (2012) Knowledge acquisition for the internationalization of the smaller firm: Content and sources. International Business Review, vol. 21, no 4, pp. 631-647.

Fuerlinger G., Fandl U., Funke T. (2015) The role of the state in the entrepreneurial ecosystem: Insights from Germany. Triple Helix, vol. 2, no 1, article 3. Available at: https://doi.org/10.1186/s40604-014-0015-9, accessed 14.05.2019.

Giroud A., Scott-Kennel J. (2009) MNE linkages in international business: A framework for analysis. International Business Review, vol. 18, pp. 555-566.

Gorg H., Hijzen A. (2004) Multinationals and productivity spillovers (GEP Research Paper 04/41), Nottingham: University of Nottingham.

Isenberg D.J. (2010) How to start an entrepreneurial revolution. Harvard Business Review, vol. 88, no 6, pp. 41-50.

Isenberg D.J. (2011) Introducing the Entrepreneurial ecosystem: Four Defining Characteristics. Forbes, 25.05.2011. Available at: http://www.forbes.com/sites/danisenberg/2011/05/25/introducing-the-entrepreneurshipecosystem-four-definingcharacteristics/, accessed 17.04.2019.

Lipsey R.E., Sjoholm F. (2004) Host country impacts of inward FDI: Why such different answers? (EIJS Working Paper 192), Stockholm: Stockholm School of Economics.

Liu Z. (2008) Foreign direct investment and technology spillovers: Theory and evidence. Journal of Development Economics, vol. 85, pp. 176-193.

Manuchehr I., Ericsson J. (2001) On the causality between foreign direct investment and output: A comparative study. The International Trade Journal, vol. 15, no 1, pp. 1-26.

Mason C., Brown R. (2014) Entrepreneurial ecosystems and growth orientated entrepreneurship (Background paper prepared for the workshop organised by the OECD LEED Programme and the Dutch Ministry of Economic Affairs), Paris: OECD.

Narula R., Dunning J.H. (2000) Industrial development, globalization and multinational enterprises: New realities for developing countries. Oxford Development Studies, vol. 28, no 2, pp. 141-167.

North D. (1990) Institutions, institutional change and economic performance, Cambridge: Cambridge University Press.

Popescu G.H. (2014) FDI and Economic Growth in Central and Eastern Europe. Sustainability, vol. 6, pp. 8149-8163.

Putnins T., Sauka A. (2015) Measuring the shadow economy using company managers. Journal of Comparative Economics, vol. 43, pp. 471-490.

Rivera-Batiz A.L., Oliva M. (2003) International trade, theory, strategies and evidence, New York: Oxford University Press.

Sauka A., Chepurenko A. (2017) (eds.) Entrepreneurship in transition economies. Diversity, trends and perspectives, Heidelberg, Dordrecht, London, New York: Springer.

Smallbone D., Welter F. (2001) The distinctiveness of entrepreneurship in transition economies. Small Business Economics, vol. 16, no 4, pp. 249-262.

Smallbone D., Welter, F. (2006) Conceptualising entrepreneurship in a transition context. International Journal of Entrepreneurship and Small Business, vol. 3, no 2, pp. 190-206.

Takki S., Ramstetter E.D. (2015) Exporting and foreign ownership in Indonesian manufacturing, 1990-2000. Ekonomi dan Keuangan Indonesia, vol. 54, no 3, pp. 315-343. DOI: 10.7454/efi.v54i3.102.

Xu D., Meyer, K.E. (2013) Linking theory and context: 'Strategy research in emerging economies' after Wright et al. (2005). Journal of Management Studies, vol. 50, pp. 1322-1346. 